\title{
Trace metals in marine copepods: a field test of a bioaccumulation model coupled to laboratory uptake kinetics data
}

\author{
Nicholas S. Fisher ${ }^{1, *}$, Ian Stupakoff ${ }^{1}$, Sergio Sañudo-Wilhelmy ${ }^{1}$, \\ Wen-Xiong Wang ${ }^{2}$, Jean-Louis Teyssié ${ }^{3}$, Scott W. Fowler ${ }^{3}$, John Crusius ${ }^{3, * *}$ \\ 'Marine Sciences Research Center, State University of New York, Stony Brook, New York 11794-5000, USA \\ ${ }^{2}$ Department of Biology, Hong Kong University of Science and Technology, Clear Water Bay, Kowloon, Hong Kong \\ ${ }^{3}$ LAEA Marine Environment Laboratory, 4 Quai Antoine 1er, BP 800, 98012 Monaco
}

\begin{abstract}
A first order bioenergetic-based kinetic model has been developed to describe metal accumulation in marine copepods. To field-test predictions of the kinetic model regarding metal. concentrations in marine zooplankton, we analyzed $\mathrm{Cd}, \mathrm{Zn}, \mathrm{Ag}, \mathrm{Co}$, and Se in water, phytoplankton, and zooplankton samples collected off the coast of Monaco. Mean concentrations in copepods were $1.3 \mathrm{nmol} \mathrm{g}$ for $\mathrm{Ag}, 22.2 \mathrm{nmol} \mathrm{g}{ }^{-1}$ for $\mathrm{Cd}, 9.5 \mathrm{nmol} \mathrm{g}$ for $\mathrm{Co}, 16.0 \mathrm{nmol} \mathrm{g}^{-1}$ for Se, and $2570 \mathrm{nmol} \mathrm{g}$ for $\mathrm{Zn}_{\mathrm{i}}$ mean dissolved metal concentrations were $10.5 \mathrm{pM} \mathrm{Ag}, 72.3 \mathrm{pM} \mathrm{Cd}, 260 \mathrm{pM} \mathrm{Co}$, and $4270 \mathrm{pM}$ Zn. For each metal, model-predicted concentrations in zooplankton using kinetic parameters for influx rates from the dissolved phase, assimilation from ingested phytoplankton, and efflux rates measured in laboratory experiments generally matched field measurements, although discrepancies were noted, especially for $\mathrm{Cd}$ where a 4 -fold difference between predicted and measured concentrations was observed. Overall, it appears that it is possible to account for the major processes governing metal accumulation from food and water in marine copepod populations.
\end{abstract}

KEY WORDS; Modeling · Zooplankton · Copepods ' Silver · Cadmium · Cobalt - Selenium - Zinc

\section{INTRODUCTION}

Zooplankton are key links in the transfer of carbon and trace elements through marine food webs. Metals can accumulate in marine zooplankton from both the dissolved phase and from ingested food. Losses of metals from zooplankton include metal excretion or metal egestion by feces production. Understanding the rates and routes of metal bioaccumulation in marine zooplankton is important for predicting their biogeochemical fates in marine surface waters. Experimental stud-

\footnotetext{
-E-mail: nfisher@notes.cc.sunysb.edu

- Present address: Lorax Environmental Services, Suite 410 1122 Mainland St., Vancouver, British Columbia V6B 5L1, Canada
}

ies have described the bioaccumulation of trace metals in marine copepods from diverse algal foods and from the dissolved phase (Fisher et al. 1991, Reinfelder \& Fisher 1991, Wang et al. 1996, Wang \& Fisher 1998a). Key first-order parameters of bioaccumulation, particularly metal assimilation efficiency from ingested food, uptake rate constants from the dissolved phase, and efflux rate constants following uptake from either food or water, were measured in these studies. By combining this information with known ingestion and growth rates of these animals, it has been possible to model the bioaccumulation of these metals in copepods using a first order bioenergetic-based kinetic model (Wang \& Fisher 1998a). This model is similar to a kinetic model developed for copepods by Ritterhoff \& Zauke $(1997 a, b)$, although the latter did not distinguish between uptake from food and from water. Assuming 
that marine animals accumulate metals from the dissolved phase and from food, the concentration of a metal in an animal $\left(C_{\mathrm{ss}}, \mathrm{nmol} \mathrm{g}^{-1}\right)$ under steady-state conditions can be described as:

$$
C_{s s}=\frac{\left(k_{u} \times C_{w}\right)}{\left(K_{e w}+g\right)}+\frac{\left(\mathrm{IR} \times \mathrm{AE} \times C_{\mathrm{f}}\right)}{\left(k_{\mathrm{ef}}+g\right)}
$$

where, $k_{\mathrm{u}}$ is the uptake rate constant of the metal from the dissolved phase $\left(\mathrm{l} \mathrm{g}^{-1} \mathrm{~d}^{-1}\right), C_{w}$ is the metal concentration in the dissolved phase (nM), IR is the ingestion rate of the animal $\left(\mathrm{g} \mathrm{g}^{-1} \mathrm{~d}^{-1}\right), A E$ is the assimilation efficiency $(\%)$ of the metal from ingested food particles, $C_{1}$ is the metal concentration in the food $\left(\mathrm{nmol} \mathrm{g}^{-1}\right), \mathrm{k}_{\mathrm{ew}}$ is the efflux rate constant from animals following uptake from the dissolved phase $\left(\mathrm{d}^{-1}\right), k_{\text {ef }}$ is the metal efflux rate constant from animals following uptake from food $\left(\mathrm{d}^{-1}\right)$, and $g$ is the growth rate constant of the animals $\left(\mathrm{d}^{-1}\right)$.

This model provides a quantitative separation of the routes of metal uptake in these animals on a metal-specific basis. The model also enables predictions to be made, on site-specific bases, about metal concentrations in zooplankton if the dissolved and phytoplankton metal concentrations are known. Note that the model considers metal accumulation that is related to physiological processes (e.g., ingestion rates, assimilation of ingested metals, excretion rates) as well as chemical factors (e.g., dissolved and particulate metal concentrations). If the model's predicted metal concentrations match closely with measured concentrations in fieldcollected zooplankton, it could be concluded that all the principal biological and chemical factors which govern metal uptake in these animals are taken into account and that the laboratory measurements of kinetic parameters are applicable to field situations. To test the field applicability of our laboratory work and the validity of the model's assumptions, we conducted a study to make field measurements of zooplankton metal concentrations using trace-metal clean techniques and simultaneously measured metal concentrations in water and in suspended particulate assemblages which serve as food for the copepods. The metal concentrations measured in copepods from the field were then compared with metal concentrations predicted by the kinetic model.

\section{MATERIALS AND METHODS}

Field sampling took place from 7 to 11 July 1997 (surface water temperature of $21^{\circ} \mathrm{C}$ ) during a copepod bloom in the Ligurian Sea off the coast of Monaco; the sampling stations in Monaco Bay are marked on 2 transects in Fig. 1. Because zooplankton are comprised of species from several different taxonomic groups, con- centrations of trace elements in undifferentiated samples are difficult to inter-compare because species composition changes over time. Therefore, it is important to separate microzooplankton down to organism type in order to get realistic estimates of trace metal content. This task becomes much easier when zooplankton blooms occur which normally involve 1 or 2 dominant species (as in the present study). Alternatively, individuals of a single species must be handpicked using a dissecting microscope, which often introduces the possibility of significant trace metal contamination.

Zooplankton were collected with surface plankton tows using an all-plastic $102 \mu \mathrm{m}$ mesh plankton net (Sea Gear Corp.). The net was placed about $2 \mathrm{~m}$ away from the boat with the help of a mechanical arm connected to a winch. Plastic sieves of 1500 and $800 \mu \mathrm{m}$ mesh size separated copepods from larger zooplankton. Copepods were allowed to defecate for $12 \mathrm{~h}$ prior to metal analysis so that measured metal concentrations primarily reflected tissue concentrations without pronounced influence of undigested food within the gut. From microscopic examination we estimate that $>90 \%$ of the gut contents were lost from the copepods. To separate fecal material from the copepods, the animals were placed into a large $40 \mathrm{l}$ modified funnel system (La Rosa 1976) where fecal pellets released by the copepods fell to the bottom of the funnel through a $100 \mu \mathrm{m}$ mesh.

Seawater samples were collected $1 \mathrm{~m}$ below the surface using a peristaltic pump equipped with acidwashed C-flex tubing in the pump head and inline filtration (acid-washed $0.2 \mu \mathrm{m}$ polypropylene cartridge filter, MSI Inc.). Water was drawn through acid-

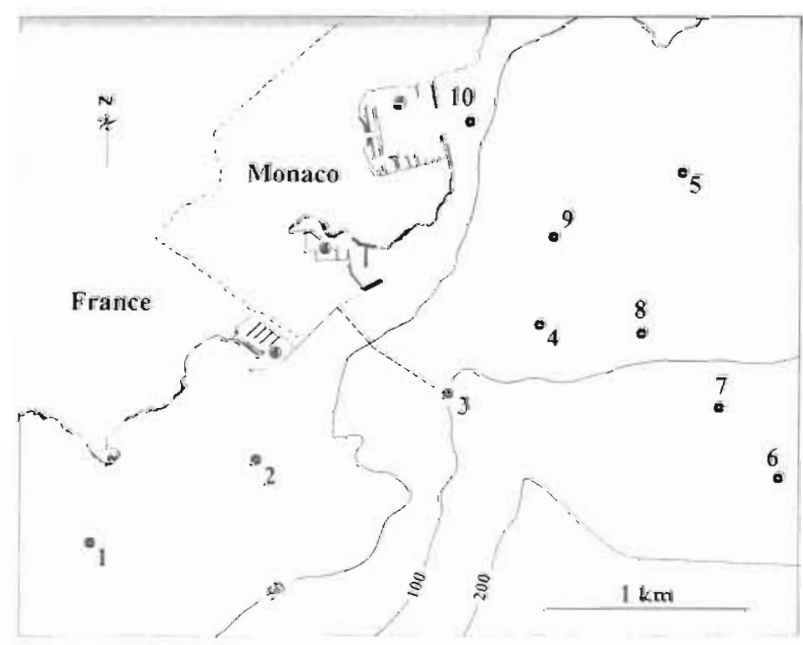

Fig. 1. Map depicting location of sample stations in the Mediterranean 
washed Teflon tubing attached to a stainless steel pole which was oriented $5 \mathrm{~m}$ upstream of the ship's drift. The tubing was allowed to purge at least 5 volumes before the sampling began. The water column protocols and acid-washed cleaning techniques have been detailed elsewhere (Flegal et al. 1991). Samples for the particulate metals were collected independently. Suspended particulate matter out of $8 \mathrm{l}$ of seawater at each station was collected on acid-washed Nuclepore filters $(0.2 \mu \mathrm{m})$ mounted on an in-line filtration system (Savillex). Microscopic examination of the filtered particulate matter indicated that phytoplankton made up a small fraction of the suspended particles, confirmed by the measured chlorophyll values. For chlorophyll determinations, water samples were collected with a plastic bucket and stored in the dark in 21 polypropylene bottles. Samples were filtered within $24 \mathrm{~h}$ through a GF/C glass fiber filter and stored at $-20^{\circ} \mathrm{C}$. Chlorophyll was extracted and analyzed according to Parsons et al. (1984a) with a Turner Designs Fluorometer. The dry weights of total suspended particles caught on tared $0.2 \mu \mathrm{m}$ Nuclepore filters were measured after drying at $80^{\circ} \mathrm{C}$.

Dissolved trace metals were preconcentrated using ammonium 1-pyrrolidinedothiocarbamate-/dimethylammonium diethyldithiocarbamate (APDC/DDDC) organic extraction (Bruland et al. 1985). Particulate matter and zooplankton samples were digested for $2 \mathrm{~h}$ in Teflon bombs immersed in boiling water with $1 \mathrm{ml}$ each of concentrated $\mathrm{Q}-\mathrm{HNO}_{3}$ and $6 \mathrm{~N}$ Q- $\mathrm{HCl}$. After this initial digestion, the samples were digested again for another $2 \mathrm{~h}$ with $100 \mu \mathrm{l}$ of Q-HF added (Landing \& Bruland 1987). Metal concentrations were determined by graphite furnace atomic absorption spectroscopy (AAS) (Hitachi 8100) with a Zeeman background correction, using standard addition protocols. As an independent check on metal concentrations in the copepods, aliquots of copepod tissue were also measured by ICP-MS, following standard protocols. Briefly, freeze-dried copepod tissues were mineralized with small quantities of high purity $\mathrm{HNO}_{3}$ in a microwave oven, taken to dryness by evaporation, redissolved in $1 \mathrm{ml} \mathrm{HNO}_{3}$ and made up to volume. Cadmium, Ag, Co and $\mathrm{Zn}$ were measured by ICP-MS using direct calibration with internal standard normalization $\left(\mathrm{Ge}_{\text {, In, }}\right.$ Re). Multiple isotopes were used wherever possible to screen for possible interferences. Results are given as an average of acceptable values. The quality of the copepod measurements was controlled by analyzing 3 different certified reference materials: DORM-1 dogfish muscle from NRCC, TORT-2 lobster hepatopancreas from NRCC, and MA-A-2/TM fish muscle from the IAEA. Our results were in good agreement (within the $95 \%$ confidence limits of expected values) with the certified values.

\section{RESULTS AND DISCUSSION}

Total suspended particle loads ranged from 0.48 to $1.44 \mathrm{mg}$ dry wt $\mathrm{l}^{-1}$ and chlorophyll a (chl a) concentrations ranged from 2.7 to $162 \mathrm{ng} \mathrm{l}^{-1}$ at all stations. The selective sieving of the zooplankton net hauls was effective in isolating adult copepods and eliminating larger or smaller zooplankton. The copepods sampled were dominated by adult calanoids, particularly Acartia clausi; other abundant species included Centropages typicus, Paracalanus parvus, and Clausocalanus $\mathrm{sp}$. Previous distribution studies have demonstrated that copepod abundance among the zooplankton off Monaco averages 60 to $70 \%$ (max. 95\%), with calanoids often being the dominant group (Corletti \& Boisson 1988)

Metal concentrations in water, suspended particles (including phytoplankton), and mixed copepods are presented in Table 1. Dissolved $\mathrm{Ag}$ ranged from 7 to $17 \mathrm{pM}$, Cd from 50 to $97 \mathrm{pM}$, Co from 200 to $322 \mathrm{pM}$, and $\mathrm{Zn}$ from 3140 to $8680 \mathrm{pM}$. Metal concentrations in suspended particles were enriched relative to ambient seawater; enrichment factors ( $k_{d}$ values) of the metals for suspended particles are plotted in Fig. 2 as a function of total suspended load and fraction of total suspended dry wt as phytoplankton (chl $a \times 200$ [Parsons et al. 1984b] divided by total particle dry wt). $k_{\mathrm{d}}$ values for suspended particles were highest for Co (10.8 \pm $\left.4.6 \times 10^{4}\right)$, followed by $\mathrm{Ag}\left(3.1 \pm 2.0 \times 10^{4}\right)$, $\mathrm{Zn}(1.8 \pm$ $\left.2.6 \times 10^{4}\right)$ and $\mathrm{Cd}\left(7.2 \pm 3.3 \times 10^{3}\right)$. Overall, these values are comparable to concentration factors for these metals in marine phytoplankton, expressed on a dry wt basis (Fisher \& Reinfelder 1995). There was no significant relationship between $k_{d}$ values for any metal and relative phytoplankton abundance, but $k_{d}$ values were negatively correlated with total suspended particle load for Co and Ag (Fig. 2), suggesting the possibility of colloidal association of these metals (Benoit et al. 1994). Zooplankton were enriched, on average, about 3 times greater than suspended particles for $\mathrm{Ag}$ and $\mathrm{Cd}$, and 50 times greater for $\mathrm{Zn}$, whereas suspended particles were 4 times more enriched than zooplankton in Co and Se (Table 1). Mean metal concentrations in copepod samples measured by ICP-MS did not differ significantly ( $p>0.05)$ from concentrations measured by AAS (Table 1).

Table 2 shows levels of selected trace elements in what are reported to be pure, or near-pure, samples of marine copepods. More information is available for $\mathrm{Cd}$ and $\mathrm{Zn}$ than for $\mathrm{Co}, \mathrm{Ag}$, or Se, and reported concentrations vary spatially. For each element, the concentrations we measured in copepods are in the range of those which have been reported previously.

Table 3 presents the mean values used in the kinetic modeling calculations. These values, based on 
Table 1. Metal concentrations in the dissolved phase, suspended particles $(>0.2 \mu \mathrm{m})$, and copepods collected at 10 stations off the Monaco coast. Dissolved Se was not measured. Mean metal concentrations in mixed copepods ( $\mathrm{nmol}^{-1} \mathrm{dry}$ wt) measured by ICP-MS were $2.39 \pm 0.84(\mathrm{Ag}), 12.8 \pm 8.2(\mathrm{Cd}), 13.3 \pm 5.0(\mathrm{Co})$, and $2320 \pm 1068(\mathrm{Zn})$, Se was not measured by ICP-MS. Modelpredicted metal concentrations in copepods are given in parentheses for each station. Concentration factors for Ag, Cd, Co, and $\mathrm{Zn}$ in copepods (mol metal $\mathrm{g}^{-1}$ dry wt animal/mol metal $\mathrm{ml}^{-1}$ water) are given in brackets. nd: not determined

\begin{tabular}{|c|c|c|c|c|c|c|c|c|c|c|c|c|c|c|}
\hline \multirow[t]{2}{*}{ Stn } & \multicolumn{4}{|c|}{ Dissolved (pM) } & \multicolumn{5}{|c|}{ Particles (nmol g $g^{-1}$ dry $\left.w t\right)^{a}$} & \multicolumn{5}{|c|}{ Copepods (nmol g-1 dry wt) } \\
\hline & $\mathrm{Ag}$ & $\mathrm{Cd}$ & $\mathrm{Co}$ & $\mathrm{Zn}$ & $\mathrm{Ag}$ & $\mathrm{Cd}$ & Co & $\mathrm{Se}$ & $\mathrm{Zn}$ & $\mathrm{Ag}$ & $\mathrm{Cd}$ & $\mathrm{Co}$ & $\mathrm{Se}$ & $\mathrm{Zn}_{\mathrm{n}}$ \\
\hline 1 & 7.6 & 81.1 & 322 & 3140 & 0.30 & 0.46 & 14.6 & 8.7 & 27.3 & $\begin{array}{c}1.57 \\
(0.52)\end{array}$ & $\begin{array}{l}17.3 \\
(6.2)\end{array}$ & $\begin{array}{c}8.16 \\
(4.88)\end{array}$ & $\begin{array}{c}12.9 \\
(8.10)\end{array}$ & $\begin{array}{c}2150 \\
(3894)\end{array}$ \\
\hline 2 & 11.6 & 85.8 & 300 & 4660 & 0.59 & 0.97 & 65.6 & 50.5 & 72.0 & $\begin{array}{c}0.66 \\
(0.82)\end{array}$ & $\begin{array}{c}14.6 \\
(5.15)\end{array}$ & $\begin{array}{c}6.97 \\
(13.0)\end{array}$ & $\begin{array}{c}17.7 \\
(47.3)\end{array}$ & $\begin{array}{c}1770 \\
(4020)\end{array}$ \\
\hline 3 & 9.8 & 59.6 & 213 & 4500 & 0.25 & 0.50 & 28.6 & 28.8 & 53.5 & $\begin{array}{c}0.67 \\
(0.64)\end{array}$ & $\begin{array}{c}21.3 \\
(4.73)\end{array}$ & $\begin{array}{c}13.4 \\
(6.40)\end{array}$ & $\begin{array}{c}14.7 \\
(26.7)\end{array}$ & $\begin{array}{c}2070 \\
(4016)\end{array}$ \\
\hline 4 & 8.6 & 49.8 & 202 & 8680 & 0.38 & 0.62 & 23.3 & 41.2 & 31.5 & $\begin{array}{c}1.64 \\
(0.60)\end{array}$ & $\begin{array}{c}23.8 \\
(4.56)\end{array}$ & $\begin{array}{c}6.78 \\
(5.46)\end{array}$ & $\begin{array}{c}21.8 \\
(38.6)\end{array}$ & $\begin{array}{c}3320 \\
(4116)\end{array}$ \\
\hline 5 & 8.6 & 58.8 & 298 & 4230 & 0.20 & 0.46 & 30.2 & 30.0 & 30.1 & $\begin{array}{c}1.79 \\
(0.56)\end{array}$ & $\begin{array}{c}22.7 \\
(4.72)\end{array}$ & $\begin{array}{c}6.71 \\
(7.26)\end{array}$ & $\begin{array}{c}8.68 \\
(28.1)\end{array}$ & $\begin{array}{c}4040 \\
(4009)\end{array}$ \\
\hline 6 & 9.2 & 76.9 & 246 & 3230 & 0.20 & 0.32 & 24.1 & 39.6 & 16.2 & $\begin{array}{c}1.49 \\
(0.60)\end{array}$ & $\begin{array}{c}35.1 \\
(5.01)\end{array}$ & $\begin{array}{c}14.3 \\
(5.90)\end{array}$ & $\begin{array}{c}16.0 \\
(37.1)\end{array}$ & $\begin{array}{c}2900 \\
(3983)\end{array}$ \\
\hline 7 & 10.6 & 57.6 & 200 & 3480 & 0.15 & 0.29 & 19.7 & 11.7 & 23.0 & $\begin{array}{c}1.37 \\
(0.67)\end{array}$ & $\begin{array}{c}18.5 \\
(4.69)\end{array}$ & $\begin{array}{c}7.82 \\
(4.86)\end{array}$ & $\begin{array}{c}15.6 \\
(11.0\}\end{array}$ & $\begin{array}{c}2870 \\
(3990)\end{array}$ \\
\hline 8 & 11.4 & 95.8 & 289 & 3420 & 0.27 & 0.42 & 23.8 & 8.2 & 19.0 & $\begin{array}{c}1.02 \\
(0.74)\end{array}$ & $\begin{array}{c}26.5 \\
(5.30)\end{array}$ & $\begin{array}{c}7.31 \\
(6.15)\end{array}$ & $\begin{array}{c}13.2 \\
(7.63)\end{array}$ & $\begin{array}{c}1340 \\
(3988)\end{array}$ \\
\hline 9 & 10.7 & 60.7 & 289 & 3440 & 0.34 & 0.49 & 22.6 & 11.4 & 52.8 & $\begin{array}{c}1.36 \\
(0.71)\end{array}$ & $\begin{array}{c}20.2 \\
(4.75)\end{array}$ & $\begin{array}{c}13.3 \\
(5.96)\end{array}$ & $\begin{array}{c}22.0 \\
(10.7)\end{array}$ & $\begin{array}{c}1770 \\
(3989)\end{array}$ \\
\hline 10 & 16.6 & 96.9 & 238 & 3930 & 136 & 0.42 & 20.3 & 50.3 & 138 & $\begin{array}{c}1.78 \\
(1.29)\end{array}$ & $\begin{array}{c}21.4 \\
(5.32)\end{array}$ & $\begin{array}{c}10.4 \\
(5.23)\end{array}$ & $\begin{array}{c}17.5 \\
(47.0)\end{array}$ & $\begin{array}{c}3470 \\
(4002)\end{array}$ \\
\hline Mean & 10.5 & 72.3 & 260 & 4270 & 0.41 & 0.49 & 27.3 & 28.0 & 46.4 & $\begin{array}{c}1.34 \\
(0.72) \\
{[1.3 e 5]}\end{array}$ & $\begin{array}{c}22.1 \\
(5.04) \\
{[3.1 \mathrm{e} 5]}\end{array}$ & $\begin{array}{c}9.52 \\
(6.51) \\
{[3.7 e 4]}\end{array}$ & $\begin{array}{l}16.0 \\
(26.2) \\
{[\text { nd] }}\end{array}$ & $\begin{array}{c}2570 \\
(4001) \\
{[6.0 \mathrm{e} 5]}\end{array}$ \\
\hline SD & 2.4 & 16.2 & 43 & 1550 & 0.34 & 0.18 & 13.4 & 16.2 & 35.0 & $\begin{array}{c}0.40 \\
(0.22)\end{array}$ & $\begin{array}{c}5.7 \\
(0.49)\end{array}$ & $\begin{array}{c}2.9 \\
(2.41)\end{array}$ & $\begin{array}{c}3.8 \\
(16.0)\end{array}$ & $\begin{array}{l}830 \\
(54)\end{array}$ \\
\hline
\end{tabular}

laboratory radiotracer experiments, were applied to each station with its dissolved $\left(C_{w}\right)$ and particulate $\left(C_{1}\right)$ metal concentrations. Although dissolved Se concentrations were not measured, this element has been consistently shown to accumulate in aquatic invertebrates, including copepods, predominantly (>98\%) from food (Luoma et al. 1992, Wang et al. 1996, Wang \& Fisher 1998a). Therefore we only modeled Se uptake from ingested food and ignored Se uptake from the dissolved phase. For the model calculations, the weight-specific ingestion rate of Acartia clausi was assumed to be at the low end of the measured range - $0.33 \mathrm{~g} \mathrm{~g}^{-1} \mathrm{~d}^{-1}$ - because of the low algal biomass in the water (Roman 1977. Mauchline 1998). Growth rate $(g)$ in adult copepods was considered negligible compared to the high efflux rate constants in copepods ( 8 to $30 \% \mathrm{~d}^{-1}$. Table 3 ). Metal concentrations in marine organisms are often assumed to be a function of the free metal ion activity in ambient seawater but exceptions have been noted (Campbell 1995, Hudson 1998). Given the uncertainties of metal complexation by dissolved organic matter at each location and the bioavailability of these complexes, we use total dissolved metal concentration $(<0.2 \mu \mathrm{m})$ rather than calculated free metal ion activity as the $C_{w}$ term. The values of $k_{\mathrm{u}}$ were based on experimental work in coastal surface seawater using total dissolved metal (Wang \& Fisher 1998a) and it is assumed that the metal complexation by the dissolved organic matter in the experimental water resulted in metal bioavailability not greatly different from that in the Mediterranean.

In our modeling, we applied physiological parameters measured at $15^{\circ} \mathrm{C}$ for adults of another calanoid copepod, Temora longicornis, to the copepods off Monaco. Although some physiological parameters (e.g., IR) may vary with different food conditions and among different copepod species, metal assimilation does not vary appreciably among different calanoid copepod species and is determined principally by metal distribution in algal cytoplasm (Reinfelder \& Fisher 1991, Hutchins et al. 1995), not by the feeding physiology of the animals or food quantity/quality (Wang et al. 1996, Wang \& Fisher 1998d). Furthermore, sensitivity analysis to evaluate the relative importance of each parameter's variability on metal concentration 

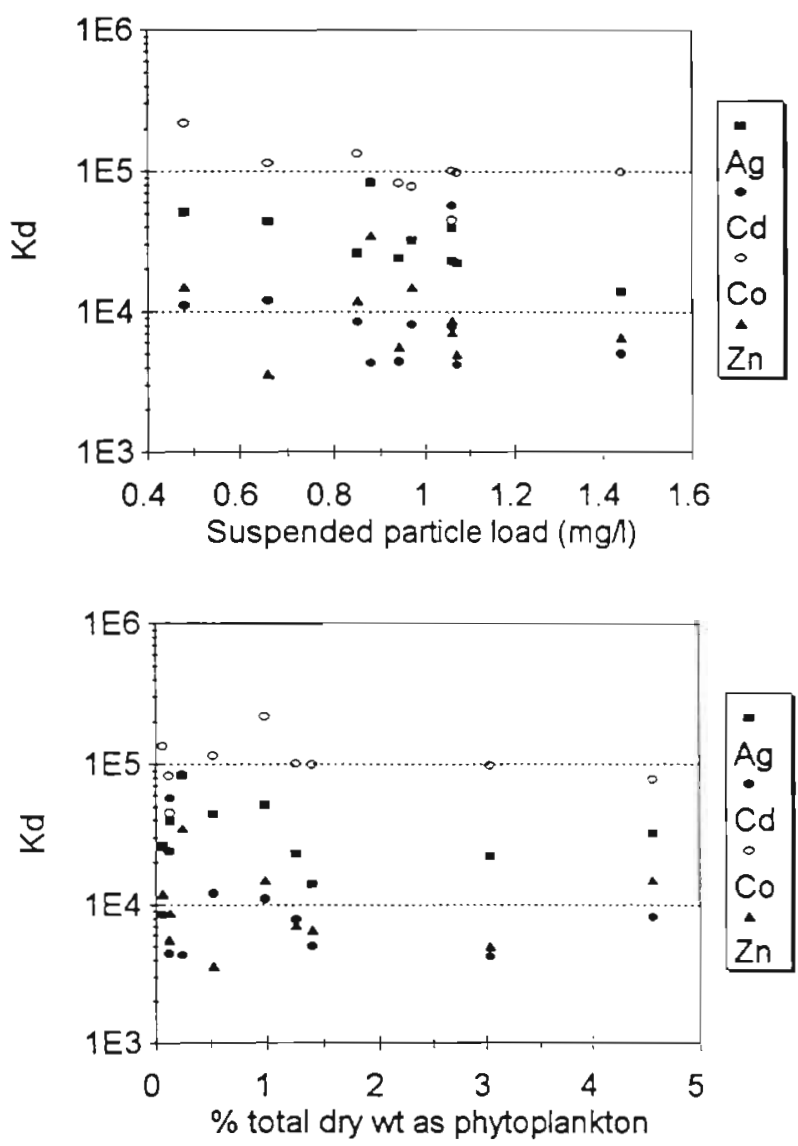

Fig. 2. Relationship between particle-water distribution coefficients $\left(K_{\mathrm{d}}\right.$ values, $\left.1 \mathrm{~kg}^{-1}\right)$ of metals and suspended particulate loads. Ag: $y=75236-42015 x, r^{2}=0.30 ; C d: y=9847+2522 x$, $\mathrm{r}^{2}=0 ;$ Co: $y=214212-115422 x, \mathrm{r}^{2}=0.413 ; \mathrm{Zn}: y=$ $19076-8199 x, \mathrm{r}^{2}=0.05$. Also shown are relationships of metal $K_{d}$ values with the proportion of total particle load attributable to phytoplankton biomass. Ag: $\mathrm{r}^{2}=0.08$; Cd: $\mathrm{r}^{2}=0.07$; Co: $\mathrm{r}^{2}=0.01 ; \mathrm{Zn}: \mathrm{r}^{2}=0.01$ in T. longicornis indicated that $>50 \%$ of $\mathrm{Ag}, \mathrm{Cd}$ and $\mathrm{Co}$ accumulates in these animals from the dissolved phase (Wang \& Fisher 1998a); thus for these metals changes in feeding activity due to change in food conditions would be expected to have only a modest effect on the overall metal accumulation in copepods. Excretion rate constants (= efflux rate constants) are generally comparable for different algal diets (Wang \& Fisher 1998 a,b). Food quantity can significantly affect the excretion rate of $\mathrm{Ag}, \mathrm{Cd}$, and $\mathrm{Co}$ but it has little effect on Se and Zn (Wang \& Fisher 1998b). Because the total suspended particle load in the Mediterranean waters we studied was low (typically about $1 \mathrm{mg} \mathrm{l}^{-1}$ ) and the phytoplankton abundance was also very low, we used the efflux rates measured at the lowest food concentrations in our model (Wang \& Fisher 1998b). Assimilation efficiencies of ingested metals in marine copepods do not vary greatly among different food types, including abiotic particles found in seston (Wang \& Fisher 1998a), so it was assumed that the metal assimilation efficiencies given in Table 3 , based primarily on work performed with unialgal cultures, would be applicable to the particle assemblage in the Mediterranean.

The metal concentrations predicted for copepods for each metal by the kinetic model are compared with the measured values for each station (Table 1). Because metal concentrations in the dissolved phase, suspended particulate matter, and copepods were all determined with AAS, we used the copepod AAS metal measurements (rather than the ICP-MS copepod data) to compare with the model-predicted values. Our modeling results indicate that metal concentrations in copepods predicted by the model were generally comparable to the metal concentrations measured in the field-collected samples. For example, the field mea-

Table 2. Comparison of trace metal concentrations in marine copepods ( $\mathrm{nmol} \mathrm{g}^{-1} \mathrm{dry}$ wt) in this study with previous reports. $\mathrm{nr}$ : not reported. Values in parentheses represent the range of measured values

\begin{tabular}{|llcccccl}
\hline Dominant species & Location & $\mathrm{Ag}$ & $\mathrm{Cd}$ & $\mathrm{Co}$ & $\mathrm{Se}$ & $\mathrm{Zn}$ & Source \\
\hline Acartia clausi & Medit. Sea & $1.3 \pm 0.4$ & $22 \pm 6$ & $10 \pm 3$ & $16 \pm 4$ & $2570 \pm 830$ & This study \\
Acartia sp. & German Bight & $\mathrm{nr}$ & $7.1 \pm 0.6$ & $\mathrm{nr}$ & $\mathrm{nr}$ & $5000 \pm 231$ & Zauke et al. (1996) \\
Temora longicornis & German Bight & $\mathrm{nr}$ & $8.8 \pm 3.2$ & $\mathrm{nr}$ & $\mathrm{nr}$ & $5846-7662$ & Zauke et al. (1996) \\
Anomalocera patersoni & Medit. Sea & $\mathrm{nr}$ & 13 & $\mathrm{nr}$ & $\mathrm{nr}$ & $\mathrm{nr}$ & Polikarpov et al. (1979) \\
Acartia clausi & Greek coast & $\mathrm{nr}$ & 5 & 5 & $\mathrm{nr}$ & 19418 & Zafiropoulos \& Grimanis (1977) \\
& & & $(4-7)$ & $(3-9)$ & & $(12232-38226)$ & \\
Calanus helgolandicus & Black Sea & $(1.2-2.6)$ & $\mathrm{nr}$ & $(9-14)$ & $\mathrm{nr}$ & $(1269-12614)$ Vinogradova \& Koval'skiy (1962) \\
Calanus plumchrus & N. Pacific & $\mathrm{nr}$ & $59 \pm 39$ & $\mathrm{nr}$ & $\mathrm{nr}$ & $1774 \pm 505$ & Hamanaka \& Tsujita (1981) \\
Mixed copepods & N. Pacific & $\mathrm{nr}$ & $68 \pm 58$ & $\mathrm{nr}$ & $\mathrm{nr}$ & $2156 \pm 688$ & Hamanaka \& Mishima (1981) \\
Mixed copepods & Monterey Bay & $\mathrm{nr}$ & $38 \pm 16$ & $\mathrm{nr}$ & $\mathrm{nr}$ & $1772 \pm 520$ & Martin \& Knauer (1973) \\
Mixed copepods & Arctic & $\mathrm{nr}$ & $(25-44)$ & $\mathrm{nr}$ & $\mathrm{nr}$ & $(917-1147)$ & Bohn \& McElroy (1976) \\
Mixed copepods & Medit. Sea & $\mathrm{nr}$ & $22 \pm 6$ & $\mathrm{nr}$ & $\mathrm{nr}$ & $4037 \pm 452$ & Hardstedt-Romeo \& \\
Mixed copepods & Medit. Sea & $\mathrm{nr}$ & $17 \pm 4$ & $\mathrm{nr}$ & $\mathrm{nr}$ & $2803 \pm 124$ & Hardstedt-Romeo (1982) \\
Mixed copepods & Medit. Sea & $\mathrm{nr}$ & $\mathrm{nr}$ & $\mathrm{nr}$ & 8 & $\mathrm{nr}$ & Boisson \& Romeo (1996) \\
Mixed copepods & Medit. Sea & $\mathrm{nr}$ & $\mathrm{nr}$ & $\mathrm{nr}$ & $39 \pm 3$ & $\mathrm{nr}$ & Cutter (1985) \\
\hline
\end{tabular}


Table 3. Mean values ( $\pm 1 \mathrm{SD}$ ) for kinetic parameters used in modeling metal concentrations in marine copepods (AE, $k_{\mathrm{u}}, k_{\mathrm{ew}}$ from Wang \& Fisher 1998a; $k_{e t}$ from Wang \& Fisher 1998b). $C_{w}$ : dissolved metal concentration, IR: ingestion rate

\begin{tabular}{|c|c|c|c|c|c|}
\hline Metal & $\begin{array}{l}\mathrm{AE} \\
(\%)\end{array}$ & $\left(1 \mathrm{~g}^{-1} \mathrm{~d}^{-1}\right)$ & $\begin{array}{c}k_{\mathrm{e}} \\
\left(\mathrm{d}^{-1}\right)\end{array}$ & $\begin{array}{r}k_{\mathrm{ew}} \\
\left(\mathrm{d}^{-1}\right)\end{array}$ & $\begin{array}{c}\mathrm{IR} \\
\left(\mathrm{g} \mathrm{g}^{-1} \mathrm{~d}^{-1}\right)\end{array}$ \\
\hline $\mathrm{Ag}$ & 0.10 & $10.42 C_{w^{\prime}}{ }^{1042}=0.073$ & $0.158 \pm 0.051$ & $0.173 \pm 0.007$ & 0.33 \\
\hline $\mathrm{Cd}$ & 0.40 & $0.666 C_{\mathrm{w}}=738=0.023$ & $0.157 \pm 0.065$ & $0.108 \pm 0.001$ & 0.33 \\
\hline $\mathrm{Co}$ & 0.15 & $0.573 C_{\mathrm{W}}^{0.873}=0.040$ & $0.304 \pm 0.040$ & $0.122 \pm 0.014$ & 0.33 \\
\hline $\mathrm{Se}$ & 0.55 & - & $0.194 \pm 0.041$ & - & 0.33 \\
\hline $\mathrm{Zn}$ & 0.60 & $2.678 C_{w} 083=0040$ & $0.078 \pm 0.018$ & $0.108 \pm 0.007$ & 0.33 \\
\hline
\end{tabular}

sured concentrations were 0.8 to 3.2 times the predicted values for $\mathrm{Ag}, 2.8$ to 7.0 times predicted values for $\mathrm{Cd}, 0.5$ to 2.4 times predicted values for $\mathrm{Co}, 0.3$ to 2.1 times predicted values for $\mathrm{Se}$, and 0.4 to 1.4 times predicted values for $\mathrm{Zn}$. Because the 10 stations were separated from each other by small distances (typically $<1 \mathrm{~km}$ ) in a well-mixed area and because the animals could swim or be transported across such distances over their lifespans, it is more appropriate to evaluate mean concentrations of metals in zooplankton samples with mean predicted values (Table 1). In so doing, the mean field measured concentrations were 1.9 times the mean predicted value for $\mathrm{Ag}, 4.4$ times the mean predicted value for $C d, 1.5$ times the mean predicted value for $\mathrm{Co}$, and 0.6 times the mean predicted values for $\mathrm{Se}$ and $\mathrm{Zn}$. Thus, the greatest discrepancy between predicted and measured metal concentrations in copepods was for $\mathrm{Cd}$. Given the errors around these means (Table 1$)$, significant differences $(p<0.05)$ were noted for $\mathrm{Cd}$ and $\mathrm{Ag}$, for which the model under-predicted the concentrations, and for $\mathrm{Zn}$, for which the model over-predicted the concentration. It is noteworthy that the greatest discrepancies between predicted and measured concentrations were only 4 -fold different from each other; given that the predictions were based on laboratory studies with a different species and that the field measurements were conducted entirely independently from the laboratory experiments, these discrepancies are not considered very great, and reasons for them are not clear One possibility is that the copepods fed selectively on the phytoplankton and avoided abiotic particles, or fed selectively on particular species of phytoplankton, and that the ingested phytoplankton had significantly different metal concentrations from the rest of the seston; that is, the $C_{1}$ term used in the model calculations was not accurate.

The relationship within and among metals for the predicted and measured metal concentrations in copepods is shown in Fig. 3. For each metal, there is some discrepancy between the model's predictions and measured values, as noted above; however among metals the model's predictions correspond with measured values quite well. This cannot be attributed sim- ply to differences in the concentrations of each metal in seawater since the elements considered here are accumulated very differently from the dissolved phase (from negligibly for Se to very high uptake rate constants for Ag; Wang \& Fisher 1998a) and display up to 16 -fold differences in overall bioconcentration factors (Table 1). The model predictions field-tested here used the mean values for the kinetic parameters given in Table 3. Sensitivity analyses (Wang \& Fisher 1998a) have shown that variations in these parameters attributable to environmental conditions and to such biological factors as copepod species, food type, and physiological state of the animals can all influence $C_{s s}$ values. However, given the relatively small variations in the kinetic parameters (Table 3 ), the predicted $C_{\text {ss }}$ values would not be expected to vary greatly from those presented here. The relatively close match between field measurements and model-predicted $C_{s,}$ values sug gests, among other things, that the mean values assumed by the model were applicable to the coastal

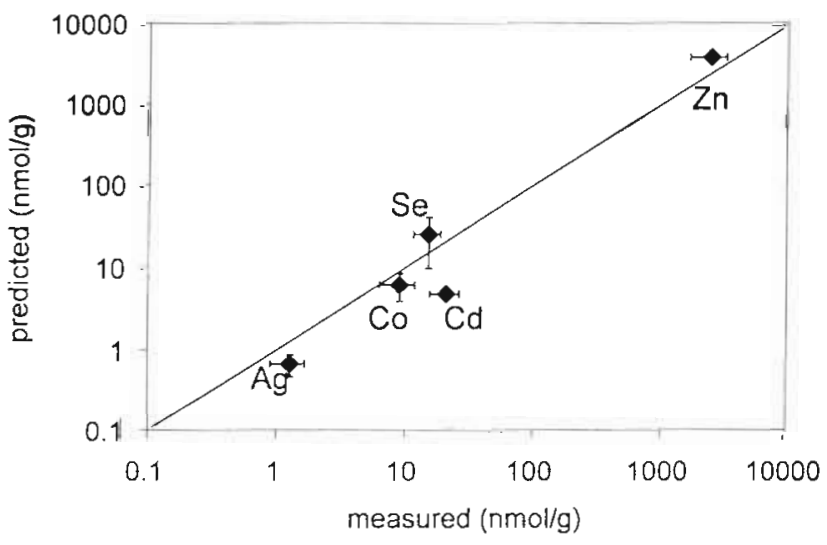

Fig. 3. Relationship between mean predicted and measured metal concentrations in copepods. The line drawn shows a hypothetical 1:1 fit. Caiculations used recently published phytoplankton concentrations $\left(C_{f}\right)$ of $1528 \mathrm{nmol} \mathrm{g}^{-1}$ for $\mathrm{Zn}$ and $4.0 \mathrm{nmol} \mathrm{g}^{-1}$ for $\mathrm{Cd}$ (Luoma et al. 1998) because some filters used for collecting phytoplankton were found to be contaminated with these metals and suspended particle measurements of these metals were considered questionable 
Mediterranean sampled in this study. Further, as noted above, the relative importance of metal uptake in copepods from food varies with each metal. Our model indicates that, for most environmental conditions likely to be encountered by zooplankton, including those prevailing in the waters sampled in this study, typically about 60 to $80 \%$ of $\mathrm{Ag}$ and $\mathrm{Co}$, about 50 to $60 \%$ of $\mathrm{Cd}_{\text {, }}$ about $20 \%$ of $\mathrm{Zn}$, and $<2 \%$ of Se are taken up by copepods directly from the dissolved phase (Wang \& Fisher 1998a). Metals accumulated from the dissolved phase concentrate primarily in the exoskeleton of crustacean. zooplankton (Fowler et al. 1970, Fisher et al. 1983, Reinfelder \& Fisher 1994), and this is reflected in fieldcollected zooplankton exoskeletons cast off during molting that are highly enriched in metals (Fowler 1977). Further, our study only considered adult copepods, both in the laboratory experiments which provided values for the kinetic parameters and the field samples which were dominated by adults. The extent to which metal uptake can be similarly modeled in juvenile copepod stages remains to be determined; certainly factors such as growth rate and rates of ecdysis could exert very different effects on $C_{s s}$ values in juveniles and adults.

With the many factors which can influence metal uptake and retention in copepods, it would seem unlikely that an identical match between $C_{\text {ss }}$ values predicted from a particular set of laboratory conditions and $C_{4 s}$ values observed in the ocean would occur for any metal. However, among the metals, given the generally close match of predicted and field measurements (which were independent of each other), it appears that it is possible to account for the major processes governing metal accumulation from food and water in marine zooplankton and that the kinetic parameters generated in laboratory experiments for monospecific copepod assemblages are applicable to at least some zooplankton communities.

Acknowledgements. We thank the captain and crew of the RV 'Vitamar' for assistance at sea, C. Gobler for chlorophyll analyses, and anonymous reviewers for helpful comments This work was funded by ONR grant No0014-95-1-1229, NSF grant OCE-9617675, and a grant from the National Association of Photographic Manufacturers to N.S.F. The IAEA Marine Environment Laboratory operates under a bipartite agreement between the IAEA and the Government of the Principality of Monaco. This is MSRC Contribution No. 1107.

\section{LITERATURE CITED}

Benoit G, Oktay-Marshall SD, Cantu A, Hood EM, Coleman $\mathrm{CH}$, Corapcioglu MO, Santschi PH (1994) Partitioning of $\mathrm{Cu}, \mathrm{Pb}, \mathrm{Ag}, \mathrm{Zn}, \mathrm{Fe}, \mathrm{Al}$, and $\mathrm{Mn}$ between filter-retained particles, colloids, and solution in six Texas estuaries. Mar Chem 45:307-336
Bohn A, McElroy RO (1976) Trace metals (As, Cd, Cu, Fe, and $\mathrm{Zn}$ ) in Arctic cod, Boreogadus saida, and selected zooplankton from Strathcona Sound, northern Baffin Island. J Fish Res Board Can 33:2836-2840

Boisson F, Romeo $M$ (1996) Selenium in plankton from the northwestern Mediterranean Sea. Water Res 30:2593-2600

Bruland KW, Coale KH, Mart L (1985) Analysis of seawater for dissolved cadmium, copper, and lead: an intercomparison of voltammetric and atomic absorption methods. Mar Chem 17:285-300

Campbell PGC (1995) A critique of the free-ion activity model. In: Tessier A, Turner DR (eds) Metal speciation and bioavailability in aquatic systems. John Wiley \& Sons, Chichester, p 45-102

Corletti V, Boisson M (1988) Observations qualitatives et quantitatives sur le zooplancton de la mer de Monaco. Rapp Comm Int Mer Medit 31:241

Cutter GA (1985) Determination of selenium speciation in biogenic particulate material and sediments. Anal Chem $57: 2951-2955$

Fisher NS, Reinfelder JR (1995) The trophic transfer of metals in marine systems. In: Tessier A, Turner DR (eds) Metal speciation and bioavailability in aquatic systems. John Wiley \& Sons, Chichester, p 363-406

Fisher NS, Bjerregaard P, Fowler SW (1983) Interactions of marine plankton with transuranic elements. III. Biokinetics of americium in euphausiids. Mar Biol 75:261-268

Fisher NS, Nolan CV, Fowler SW (1991) Assimilation of metals in marine copepods and its biogeochemical implications. Mar Ecol Prog Ser 71:37-43

Flegal AR, Smith GJ, Gill GA, Sañudo-Wilhelmy S, Anderson LCD. Branica M (1991) Dissolved trace element cycles in the San Francisco Bay estuary. Mar Chem 36:329-363

Fowler SW (1977) Trace elements in zooplankton particulate products. Nature 269:51-53

Fowler SW, Small LF, Dean JM (1970) Distribution of ingested zinc-65 in the tissues of some marine crustaceans. J Fish Res Board Can 27:1051-1058

Hamanaka T, Mishima S (1981) Cadmium and zinc concentrations in marine organisms in the northern North Pacific Ocean. Res Inst Pac Fish Hokkaido Univ Spec Vol, p 191-206

Hamanaka T, Tsujita T (1981) Cadmium and zinc concentrations in zooplankton in the Subarctic region of the North Pacific. J Oceanogr Soc Jpn 37:160-172

Hardstedt-Romeo M (1982) Some aspects of the chemical composition of plankton from the north-western Mediterranean Sea. Mar Biol 70:229-236

Hardstedt-Romeo M, Laumond F (1980) Zinc, copper and cadmium in zooplankton from the N.W. Mediterranean Sea. Mar Pollut Bull 11:133-138

Hudson RJM (1998) Which aqueous species control the rates of trace metal uptake by aquatic biota? Observations and predictions of non-equilibrium effects. Sci Total Environ 219:95-115

Hutchins DA, Wang WX, Fisher NS (1995) Copepod grazing and the biogeochemical fate of diatom iron. Limnol Oceanogr 40:989-994

Landing WW, Bruland KW (1987) The contrasting biogeochemistry of iron and manganese in the Pacific Ocean. Geochim Cosmochim Acta 51:29-43

La Rosa J (1976) A simple system for recovering zooplankton fecal pellets in quantity. Deep-Sea Res 23:995-997

Luoma SN, Johns C, Fisher NS, Steinberg NA, Oremland RS, Reinfelder JR (1992) Determination of selenium bioavailability to a benthic bivalve from particulate and solute pathways. Environ Sci Technol 26:485-491 
Luoma SN, Van Geen A, Lee BG. Cloern JE (1998) Metal uptake by phytoplankton during a bloom in South San Francisco Bay: implications for metal cycling in estuaries. Limnol Oceanogr 43:1007-1016

Martin JH, Knauer GA (1973) The elemental composition of plankton. Geochim Cosmochim Acta 37:1639-1653

Mauchline J (1998) The biology of calanoid copepods. Adv Mar Biol 33:1-707

Parsons TR, Maita Y, Lalli CM (1984a) A manual of chemical and biological methods for seawater analysis. Pergamon, Oxford

Parsons TR, Takahashi M, Hargrave B (1984b) Biological oceanographic processes, 3rd edn. Pergamon, Oxford

Polikarpov GG, Oregioni B, Parchevskaya DS, Benayoun G (1979) Body burden of chromium, copper, cadmium and lead in the neustonic copepod Anomalocera patersoni (Pontellidae) collected from the Mediterranean Sea. Mar Biol 53:79-82

Reinfelder JR, Fisher NS (1991) The assimilation of elements ingested by marine copepods. Science 251:794-796

Reinfelder JR, Fisher NS (1994) Retention of elements absorbed by juvenile fish (Menidia menidia, Menidia beryllina) from zooplankton prey. Limnol Oceanogr 39:1783-1789

Ritterhoff J, Zauke GP (1997a) Bioaccumulation of trace metals in Greenland Sea copepod and amphipod collectives on board ship: verification of toxicokinetic model parameters. Aquat Toxicol 40:63-78

Editorial responsibility: Otto Kinne (Editor), Oldendorf/Luhe, Germany
Ritterhoff J, Zauke GP (1997b) Evaluation of trace metal toxicokinetics in Greenland Sea copepod and amphipod collectives from semi-static experiments on board ship. Polar Biol 17:242-250

Roman MR (1977) Feeding of the copepod Acartia tonsa on the diatom Nitzschia closterium and brown algae (Fucus vesiculosus) detritus. Mar Biol 42:149-155

Vinogradova ZA, Koval'skiy VV (1962) Elemental composition of the Black Sea plankton. Dokl Akad Nauk SSR 147:1458-1460

Wang WX, Fisher NS (1998a) Accumulation of trace elements in a marine copepod. Limnol Oceanogr 43:273-283

Wang WX. Fisher NS (1998b) Excretion of trace elements by marine copepods and their bioavailability to diatoms. J Mar Res 56:713-729

Wang WX, Reinfelder JR, Lee BG, Fisher NS (1996) Assimilation and regeneration of trace elements by marine copepods. Limnol Oceanogr 41:70-81

Zafiropoulos D, Grimanis AP (1977) Trace elements in Acartia clausi from Elefsis Bay of the upper Saronikos Gulf, Greece. Mar Pollut Bull 8:79-81

Zauke GP, Krause M, Weber A (1996) Trace metals in mesozooplankton of the North Sea: concentrations in different taxa and preliminary results on bioaccumulation in copepod collectives (Calanus finmarchicus/c. Helgolandicus) Int Rev Ges Hydrobiol 81:141-160

Submitted: August 11, 1999; Accepted: October 27, 1999

Proofs received from author(s): February 29, 2000 